\title{
Review the legal challenges of supporting economic crimes victims
}

Revisión de los desafíos legales para apoyar a las víctimas de delitos económicos

Farzaneh Morshedi*

Islamic Azad University Kermanshah - Iran

Hossein Gholami**

Allameh Tabatabai University - Iran

\begin{abstract}
Economic crimes in industrialized developing countries, especially in Iran, constitute an important level of crime. The main nature of these crimes and the deep-seated tragedy of its victims in various areas, in addition to the wide range of economic crimes and the number of genuine and legal victims, and in particular the economic system, distinguish these crimes from other crimes. The support of this group of victims in various areas can be evaluated and reviewed. The most important type of support is legislative support, which anticipates various actions in this area, in the wake of several different laws by adopting various laws. But by examining the relevant laws, we find that only legitimate legislature has failed to take the necessary steps to support these perpetrators, in which numerous factors have affected it. In this article, one can examine some of these causes, including legislative changes, the inappropriateness of penalties, legislature vacuum, and so on.
\end{abstract}

Keywords: economic crime, legislative support, victims of economic crimes.

\section{RESUMEN}

Los delitos económicos en los países industrializados en desarrollo, especialmente en Irán, constituyen un nivel importante de delincuencia. La naturaleza principal de estos delitos y la profunda tragedia de sus víctimas en diversas áreas, además de la amplia gama de delitos económicos y el número de víctimas genuinas y legales, y en particular el sistema económico, distinguen estos delitos de otros. El apoyo a este grupo de víctimas en diversas áreas puede ser evaluado y revisado. El tipo de apoyo más importante es el apoyo legislativo, que anticipa diversas acciones en este ámbito, a raíz de la adopción de diversas leyes. Sin embargo, al examinar las leyes pertinentes, encontramos que sólo la legislatura legítima no ha tomado las medidas necesarias para apoyar a estos perpetradores, en lo que han influido numerosos factores. En este artículo, se pueden examinar algunas de estas causas, incluyendo los cambios legislativos, la inadecuación de las penas, el vacío de la legislatura, etc.

Palabras clave: delito económico, apoyo legislativo, víctimas de delitos económicos.

\section{RESUMO}

Os crimes econômicos nos países em desenvolvimento industrializados, especialmente no Irã, constituem um importante nível de criminalidade. A natureza principal desses crimes e a profunda tragédia de suas vítimas em diversas áreas, além da ampla gama de crimes econômicos e do número de vítimas genuínas e legais, e em particular o sistema econômico, distinguem esses crimes de outros crimes. $\mathrm{O}$ apoio deste grupo de vítimas em várias áreas pode ser avaliado e revisto. $\mathrm{O}$ tipo mais importante de apoio é o apoio legislativo, que antecipa várias açóes nesta área, na esteira de várias leis diferentes, através da adoção de várias leis. Mas ao examinar as leis relevantes, descobrimos que apenas o legislador legítimo não tomou as medidas necessárias para apoiar estes perpetradores, nos quais numerosos fatores o afetaram. Neste artigo, pode-se examinar algumas dessas causas, inclusive mudanças legislativas, a inadequação das penas, o vácuo legislativo, etc.

Palavras-chave: crime econômico, apoio legislativo, vítimas de crimes econômicos.

${ }^{*} \mathrm{PhD}$ Student of Jurisprudence And Principles Of Islamic Law, Yadegar-e-Imam Khomeini(RAH) Shahre Rey Branch, Islamic Azad University, Tehran, Iran.

${ }^{* *}$ Corresponding author. Associate Professor, Department of Jurisprudence and Principles Of Islamic Law, Shahid Motahari High School University, Tehran, Iran.

Recibido: 03/06/2019 Aceptado: 07/08/2019 


\section{Introduction}

What is today as an economic offense involves damage to the system of economic distribution and consumption. The economic crime is one of the concepts of industrial and developing societies, which, due to the numerous direct and indirect effects of these crimes on various aspects of the society, and the long-term consequences of its victimization has attracted attention of legislators. By examining the concept of economic crime and its sociological point of view, one of the most important goals is the recognition and control of economic crimes and the advent of its negative effects in the economic and legal system of the country, because it serves to protect victims. Recognizing the economic crimes and their failure to recognize the harm of any economic system and, consequently, of the social and cultural structures of the country, should be explored, and it should be possible to examine and identify the victims of economic crimes and legal problems in support of the arrests in the present article, a brief description of the economic crime and its definition of victimization is addressed to the explanation of these challenges, including the fact that existing laws governing economic crimes are due to the dispersion of the time of adoption and the lack of conformity with the current needs of society. The absence of a definite definition of the economic crime of overcoming plans for lack of transparency the lack of harmonization of laws and the need for expert supervision and control of the rules and regulations and the complexity of the laws. In addition to not understanding the law and the law, it makes it difficult to make decisions and to overcome inequalities and undermine legal security. Also, the lack of prediction of supportive mechanisms for compensating the victims of these crimes and international non-cooperation, as well as the lack of proportionality of penalties in the economic process, are some of the supporting challenges in the field of legislation on these crimes, which has, moreover, provided that victims of economic crime support it also does not suit the vulnerability of these perpetrators.

\section{A. Definition of economic crime}

There is no single definition of economic crime by lawmakers and lawyers, and there is no consensus on domestic economic law in defining economic crime (Najafi Ebranabadi, 2005: 52). Due to the economic system, and in each period, according to the requirements, a specific concept of economic offense has been taken and the term "offense" the economics of the current concept since the "white-collar offender" plot by sutherland american criminology in 1939 was considered (Mahdi Pour, 2002: 55) foreign lawyers have also provided several definitions of economic crime, including economic crime, in the wider sense of the whole of the general sovereignty and the safeguarding of the means of production and the regulation of agriculture, agriculture, and agriculture, and threatens to inflict losses on the national economy or on the profit of an illegitimate and non-legal person. (Seraj, 1998: 119). In the republic of china, the economic offense is not a term in the criminal law, the term is defined by the ministry of justice, any activity that violates the law and violates the economic system or violates the principle good faith in trading or gaining profit illegally d. (Massoudi, 1392: 172) in the international arena, although no international or regional conventions have so far been explicitly called for "economic crime", the share of economic crimes is remarkable in this respect, as many conventions have so far some forms of economic crimes have focused on money laundering in the context of financial corruption, including the palermo mérida conventions.

Many lawyers believe that economic crimes are in the field of economic criminal law and are aimed at protecting macroeconomic policies in the community, which guarantee healthy and healthy economic activities. (Kusha, 2008: 12). Others also believe that crimes committed against the economy of the country are committed. They are either intended to do so, or in effect, disrupt the economic system of the country, and the ultimate goal is a huge financial benefit (Saki, 2010: 26) the scientific council of the Islamic council in 2005 looks at the definition of economic crime with a security look and proposes definitions that include more examples: "all behaviors and behaviors that disrupt the economic system or function of all centers. Economics ranges from small units to disturbances in the overall economic system of the country. " (Panayio, 2001: 70,78), in this definition, has had a profound look at the results of economic crimes and economic misery and their direct vision, which has taken into account the security and government perspective, and did not focus on the structure of the economic system, and only disturb the economic system the criterion and the criterion.

In the definition of economic crime, it can be said that any behavior against economic activity in the sphere of consumption and, in particular, of the economic system in a set of laws is intended to protect the single members of the community and the economic system of criminalization and punishment.

\section{B. Definition of economic crime victims}

Economic crimes are among the direct and indirect offenders, with a wide range of victims in this category. Persons who are directly harmed by economic crimes suffer from the economic crime they cause are, in principle, the direct victims of such crimes. In the process against the consumer, people and society are the direct victim of these crimes. In the course of their prosecution, the community as a direct victim is subject to victimization.

But in the economic process, the greatest victim of the economic system is that the effects of this victimization on the economic fabric lead to the victimization of each individual in society. For most economists, though, the government's victimization is indirect in a crime such as bribery or crimes against the consumer, but it will create an inalienable harm to the direct victim. The victims of the economic crime of the state and the people as customers in the case of price manipulation, poor quality of products or services, even the environment, are at the same time incongruous victims of economic crime, and tax evasion also leads to a deficit in government revenue and the 
government's weakening in the provision of services, direct to my people.

The realization of economic crimes has led to the failure to fulfill the legal and regulatory objectives in the economic and commercial structures and consumption in the society and the individual societies. The public trust that is a source of healthy economic activity provides for the victimization of the economic system of society.

\section{- Explaining the legal challenges of economic crime in support of its victims}

The subject of regulatory challenges in the field of support for economic crime will be the reflection of the lack of support to befriendly people. In this regard, some factors are being investigated.

\section{The plurality and diversity of legislative bodies}

The plurality of law enforcement agencies has not led to a single criminal policy on economic crimes that is being undermined by the interference of other non-parliamentary bodies in the legislative process and the adoption of laws that are often "illegal". It also makes it difficult to identify and resolve the rules of law. Therefore, some of the references are mentioned below:

\subsection{Legislature}

In the field of economic crimes, in general, and in particular, such as the law on the fight against money laundering, the law on customs and the prohibition of the issuance of a patent in foreign proceedings, or on a case by case basis in the form of materials from the Islamic penal code, has been legislatively disputed. This is one of the challenges of Iran's laws on economic crimes has eaten. To the extent that the exact number of economic crimes can not be identified and identified. It's a very difficult thing to do with the unwritten laws of obsolete laws.

In accordance with article 4 of the constitution, it is specifically criminalized and punishable by the exclusive right of the Islamic consultative assembly. What is convinced of is the fact that, according to article 85, a person is a party to the delegation, and the immigrant can not delegate self-regulatory self-governing self-governing self-governing commissions to yahyat. However, in addition to these references, there are other provisions that have been found by the law enforcement agencies of the Islamic republic of Iran, including the judiciary and the expediency council, which will be addressed as follows.

\subsection{The Judiciary}

Article 85 of the constitution (3) article 156 of the constitution, where a parliament can not delegate legislative power to a person or board, with the exception of its internal commissions, however, in accordance with article 72 of the constitution, this power is unenforceable and can not be legislated. In order to carry out internal affairs, it is possible to draw up a directive or a directive in order to perform the assigned duties under the laws approved by the majlis, but none of these cases should not be adhered to or otherwise disadvantaged because the position of the representative is to the person and not transferred to non and this is only the parliament in general, it can legislate. The issuance of guidelines for the investigation of economic crimes and the establishment of special departments under the name of the ministry of economic affairs is the policy of the head of the judiciary, which has been legally and gravely resolved, since, basically, "giving the title of the instruction for dealing with the afc is a form of writing of the law that is in the competence is the legislator.

\subsection{Expediency Council}

In accordance with article 112 of the constitution, the expediency council considers the expediency in cases where the resolution of the Islamic consultative assembly and the guardians are contrary to the provisions of the shari'a or the constitution, and the magistrate does not provide the guardian council with due regard to the expediency of the system, or advising on the matters to which the leadership refers. And the duties set forth in the basic law are made on the instructions of the leader. Major penal laws of the majlis have been approved by the expediency council of the revolution in response to economic crime. The law on the application of government sanctions on smuggling of goods and currency is 12.2 / 74, the law of exacerbation of punishment of banknotes and the importers, distributors and consumers of foreign currency notes 68/1 / 68. It seems that the legislative expediency of the expediency council is based on article 10 of article 110 of the law the basic philosophy of the forum is the formation of a congressional assembly and the adoption of legislation and regulations.

It is desirable that the laws of economic crimes be passed through the parliament, with the consent of the specialized committees and the main experts in deciding on the issues and issues of society. Therefore, the democratic principles are more compatible and more consistent with the views of the people. In addition, the legislative process, as mentioned, would reduce the number of law enforcement agencies, there are a lot of laws that can not be expected of people from all laws and regulations, and they are aware that the rules are necessary for the general public, provided that they are in any event in addition, a large number of legislative acts in the field of economic crime cause non-overlapping of rules and regulations, and cause abusers, especially white-collar criminals, who, having regard to their influence, can file documents before entering the criminal justice process. Considering that this category of damage to the victims of these crimes. 


\section{Lack Of Standards On Crime And Criminal Offenses}

In many cases, most of the economic crimes have been accelerated by scrutiny and have been approved by law, and therefore without any definition of economic crime, they have predicted punishments in these disputed laws that most of these crimes are committed between offenses. And the extent of the damage done to the victim and the society has not been proportionate, therefore, we have faced no legislation on the phenomenon of inflation, and this neglect has not provided enough support for the victims of these crimes, which we are discussing in these paragraphs.

\subsection{Inaccuracy}

In defining economic crime, with the adoption of the Islamic penal code of 92, examples of economic crimes of darband (b) article 109 include economic crimes, including fraud and theft of the subject matter of note 136 of this law, but due to the multiplicity of offenses and related costs associated with it and the number of laws supporting these crimes as a legitimate element of them, or laws that play a complementary role, we are still faced with a lack of coherence in the definition of economic crime and its application. The crime of fraud constituting an economic crime is a crime against property and property which is the real victim of that person, but who is suffering from economic crimes of the general public, especially the economic system, and simply "by setting the ceiling for the amount of crime, the nature of the crime can not be changed. The fraud has not been removed from the country's economy and its ownership has been unjustly changed. In the event that economic crime leads to the withdrawal of capital and other factors of production and economic prosperity from the country, it results from the recession and economic loss or the loss of huge resources and resources.(Hashemi Shahroudi, 1396: 19)

\subsection{Disproportionate Crime With Punishment}

By examining the laws, we find that the lawmakers have not taken appropriate punishment according to the type of economic crime. For example, the punishment for interference by foreign ministers in foreign affairs is due to their influence in the government's economic and commercial centers, which is insufficient due to the extent of the losses incurred by the public sector and the public against the payment of a public servant to the government, in particular the loss of public confidence in the sovereignty. Tax crimes are important because of the effects they have on the economic system, but they seem to be part of minor crimes. Another important economic crime is money laundering, which, first, was not a criminal offense until the year 86, and secondly, "there is little punishment for it after criminalization." regarding the smuggling of goods and property, the authorities are seeking to enforce noncriminal proceedings and exercise their punishment. The more intense immediately after payment of a fine with a tolerance increased the likelihood of committing this crime by raising the amount of the property. It seems that criminalization in the form of government decrees and the regulation of state regulations reduces the commission of this crime and prompts professional offenders they are looking for the opportunity and the opportunity to use legal vacuum it is also noteworthy that with the prediction of some institutions, including the deferral of punishment in the fifth chapter of the Islamic penal code, approved by article 92 (article 40), the suspension of punishment in the sixth paragraph (article 46) in the eighth paragraph of the conditional release (article 58), chapter ix, alternate sentences of imprisonment (article 64), amnesty against repentance in the first chapter of chapter 11 (articles 98-96). However, the capt. Military (c) article 47 of the act criminalizes economic offenses of more than one hundred million rials suspending and punishing the punishment, but in light of the legislator's shortcomings in identifying instances of economic crime, many of the crimes that are the subject of sadi, but they have not been given their malpractice for such crimes, such as stock market criminals,... Has left open the way for criminals to use the above institutions.

\subsection{Crime-Based Crime}

In the criminalism of politics, with the disregard for scientific findings, they seek to restrict the general sentiment and order of society, especially after the occurrence of major crimes, so that the influence of the emotional atmosphere of the community is emphasized by the will of the people. And the conditions of social life are features of criminal-based social policies (Windzio, 2005: 259-285)

Nonetheless, resorting to extremist offenses and the development of criminal law interventions is a sign of the weaknesses, weaknesses and disadvantages of the governing body to take appropriate measures in the aftermath of the events. Inflation will have criminal laws. In this category, it is possible to urgently refer to the rules and the rules of non-expert law.

\subsubsection{The Following Rules Apply}

The subject of economic development in the light of the nature and effects of these crimes can be rightly taken in order to support its views, which will be adopted outside of the realm. An immediate hearing in the judiciary will allow for a thorough examination and will result in serious neglect of the various aspects of legislation. (Moradi, Afzali, 2011: 34; Mohammadi, 94: 1)

When legislation is based on the bill, the government's public needs are based on the information provided by the 
executive and the undergraduate studies on the basis of available information better than the deputies. 3 therefore, the submission of 305 proposals by the deputies to 124 is not good, but represents a problem in the legislative system. . The parliament's success is in the early adoption of the necessary and effective legislation in the face of the problems of society. Therefore, a bill based legislation can enforce the system of regulation. Legislative system requires the adoption of partial laws and not general rules.

\subsubsection{Understanding The Rules}

Approval of laws requires expertise and review, so the laws that are approved on the basis of the expediency and lack of necessary expertise in order to reduce the incidence of accidents are not sufficiently effective for the long term. One of the most important examples of these crimes is the law of the ethics in the economic system of the republic of Iran, adopted in 1369 with subsequent amendments, which, in view of the post-war economic turmoil of the legislator, is based on the important demands and the anticipation of a solution to the economic problems of peace in the community. Was. Therefore, the important points in the application of this law to the use of the terms "major and guardians" and the mention of the examples of crimes in the form of allegory indicate that there is a lack of expertise on the above law, insofar as the quantitative criterion may be due to the inclusion of few people who have a security approach oriented as a significant means of non-academic hard-line approaches in the economic process.

Another example of this type of crime is the lack of a stabilized exchange market situation in the year 91, which led to protests against the turmoil of the currency and the daily inflation of commodity prices, which led parliamentarians to try to contain the crisis on february 17,2012 , urgently voting plans and heavy penalties for disturbing the foreign exchange market through formal currency transactions, resale of foreign currency, foreign currency transactions outside the legal and mafia network. Cash penalty, imprisonment up to 25 years, and in cases of corruptor on earth. Execution. In this category there is also a point of censure in socialism. It is when the dayto-day economic policies of the economy require the abandonment of the principles and legal standards of mild and courteous criminal policies and the concept of actual struggle with corruption is dimmed. (John, 2006: 331)

The policies adopted in the anti-money-laundering law are a clear example of the ineffectiveness of unequivocal legal principles and criminological flexibility without rational justification. With the explanation that money laundering in Iran has been subject to resilience and, in the end, a slight punishment compared with the penalties imposed for crimes such as theft, fraud and ... For the offense is foreseen. Such a procedure would reveal the legislator's influence on public opinion in politics. Obviously, the people of the community know little about the crime and are unaware of its effects and consequences. Consequently, regulatory legislation, ignoring the fact that in the long run an unhealthy economic environment resulting from money laundering will change the attitude of the people from the political system, has passed a law that puts the perversity and distrust of the legislative system above all else. (Rahbar, 1387: 22). This law is solely for the sake of the title of the anti-money laundering law. Despite the fact that the nature of the punishment must be as close as possible to the crime, a quarter of the money earned for money laundering has certainly not been supported by its victim.

\section{Unprofessional Rules}

One of the major challenges to protecting victims of non-professional economic crimes is some laws, because, as noted, the mere criminalization and punishment and the adoption of non-criminal laws to meet the needs of these victims are not enough. Because the punishment of the perpetrator, who imposes many costs on society, does not compensate for the victims of economic crimes, and in most of these criminal offenses, victims have been required to sue for compensation. Under a restitution law, the perpetrators of embezzlement and fraud committed by the expediency council the system refers to the owner of the property for the rejection of the principal's property, but in article 42 of the monetary and banking law of the country it is not mentioned. It is also necessary to submit a petition for losses in foreign exchange offenses to return the currency to the country's banking system in article 42 of the said law because it merely determines the punishment of importers of goods that have entered the goods for the purpose of transferring foreign currency abroad. In this regard, in order to compensate for the legal misdemeanor in the matter, the central bank's legal department to repatriate the currency transferred from article 214 of the Islamic penal code of 9213, which stipulates that the offender must be financially educated if committed, if not available, if not. Either the price is passed on to the owner and it can also bear the damages ... The private conflict caused by the crime, which generally has a civil characteristic, is raised. Therefore, the central bank as the private contender must initiate the first hearing on the filing of a claim for damages for the refund of the currency resulting from the crime. In addition, there is a need to pay the cost of proceedings in respect of compensation for losses incurred as a result of crime, as well as the entry into the process of legal proceedings in accordance with the civil procedure code, which, according to their length of time, is long. If the main purpose of the victim is a criminal complaint for the restoration of victimization and compensation, and if the legislator, in the same way as the other offenses, considers this compensation to be legal rules, it will certainly be discontinued after a long period of crime and crime the victim will be compensated, in particular, that the payment of the trial for filing a petition would impose a cost on the victim's costs of those crimes. However, the municipality would have to provide compensation for the victim's loss of property. They do not know the petition, but in the economic crimes that their perpetrators are every single person the community is subject to the petition. 
It is also one of the most widespread victims of economic crimes in the field of consumer rights, which is not in Iran's civil law rules of conscience and justice.

Even with the use of the rules and regulations of the civil liability law which, according to the date of its adoption, implied the cases of loss and imprisonment in civil law, but with regard to the entry of the losses to the consumer and its proof and their causal relationship, which the newer and more stringent rule for consumer rights, it still can not answer the problems and complexities of today's consumer market, because, in addition to the passage of time, the industry and consumer technology market have undergone a deeper evolution. It can be said that due to the lack of attention to sufficient knowledge of society and rewriting of the rules and rules of jurisprudence and islam the idea and the unity of the arrow did not allow the formation of an acceptable rule for the provision of consumer rights. As the legal procedure and procedural unanimous opinions have been less well-documented in this case, it has compensated the victim (consumer) according to the civil liability law. Therefore, we find that the existing laws and regulations do not have the power to pay for the overwhelming majority of victims of economic crimes and support them, according to the characteristics of these crimes, and have worked unprofessionally.

\section{Shortcomings Related To International Cooperation}

A dream with economic crime, especially in terms of transnationality, is not the result of domestic and international cooperation. Given the fact that today most economic crimes through electronic and electronic exchanges, as well as multinational corporations in the field of economic crimes, do not benefit from domestic frontiers in support of the victims of these crimes. Therefore, in this category, we can use judicial assistance, which is "the sum of the means by which a state, in order to assist another government, public forces or judicial institutions in the service of investigation and enforcement and the execution of a sentence that the other state has requested" (Ardebili, 2005: 22). One of the issues related to this area is the fact that in Iran there are no provisions for the international prosecution, but with regard to the accession of Iran to the merida convention, the implementation of the procedure has been provided as a form of judicial assistance. But one of the important issues of extradition is to "recover the accused or convicted person from the country where the accused or convicted is resettled after the crime was committed before or after trial or after trial or before the sentence was executed." (Gholdozian, 2008: 121 ) since no country has returned its nationality to another state, the meridian convention provides, in article 41, paragraph 11, that the requested state is required, in case of non-extradition, to submit the item without undue delay to the competent authorities prosecuting the offense of delivery and the authorities will make their own decisions in the same way as they do about any other crime. In Iranian law, the issue of the extradition of offenders subject to certain laws, including article 77 of the constitution of article 9 of the civil code, the circular no. $529 / 2398$ dated $4 / 2 / 1335$ of the ministry of justice on how to regulate the documents for extradition, as well as the law on extradition of criminals approved in 1339 however, by joining the un convention against corruption and the un in 2008, Iran has taken a step forward. But the actual rules of law in this category have not been drafted, but merely the adoption of symbolic and unrealistic rules to pave the way for accession to the treaty, which does not guarantee the implementation and is not sponsored by any of the safeguards of separate acts of this convention. In addition, it is important that the laws on economic crimes, in particular those relating to disturbing the economic system, which include the death penalty for criminals, are an obstacle to the extradition of offenders, since european countries are obligated to extradite criminals who their verdict is against human rights.

\section{Legislative Vacuum}

In the field of economic crime, in addition to the failure to define the economic crime mentioned earlier, there are some opportunities that illegally use financial resources through the exploitative and economic exploitation of some individuals through acquaintances who have this influence. Earning wealth is a huge pest for the economic system, which is referred to as rent, which has not been criminalized. There are currently disputed rules regarding indirect renditions or special provisions, such as the securities exchange act concerning the use of tacit information or the law on the promotion of public health in relation to the definition of corruption and the law implementing general policies of article 44 of the constitution., about the validity and breach of a healthy economic competition, but none of these rules are explicitly related to rentier crime. This legislative gap has made the judges pass judgment on the interpretation of the law and offset the coverage of such phenomena with other laws. At present, a renditions crime bill has been drafted, which has also been noted in the merida convention. So, by adopting such laws, there will be plans to abusive the legal vacuum for offenders, especially white-collar criminals.

Article 1 anyone who, contrary to legal or healthy economic competition, exercising his or her credentials or other power, exercising political or economic influence, or abusing unsolicited information without creating or producing productive economic activities or raising the level of value added and interest $\mathrm{zn}$ in the community to study any property or privilege illegal, rentier is considered and punished as follows:

(a) if rendition has resulted in the acquisition of the property, the punishment in addition to recording it in favor of the state is as follows:

Whenever the amount of the proceeds or the proceeds of the gain is up to a billion rials, the imprisonment and cash penalty (6) 
If the amount exceeds one billion rials to one hundred billion rials, the amount of cash imprisonment (5)

If the amount is more than one billion rials, the amount of cash imprisonment (4)

B) the penalty for rendering, if any, leads to a non-monetary gain, in addition to the revocation of the privilege, is subject to imprisonment and a fine of six.

Note: determining whether the activity commits logic to a healthy economic competition or whether it leads to increased interest and value added in the community is the responsibility of the competition council referred to in article 44 of the constitution's implementation policies act.

Article 2 the renditions of a person in respect of a person, in addition to the confiscation of property, proceeds and benefits received in favor of the government and the cancellation of the points obtained, in accordance with the provisions of paragraphs (a), (b), and one or two of the penalties the provisions of article 20 of the Islamic penal code are approved.

It is worthy of note that the legislators have set out different rules for the reporting of supervisory bodies, but a large number of regulatory agencies and regulatory agencies in relation to the regulatory and regulatory framework between regulatory agencies have led to parallel activities and high cost inputs for the protection of economic crime. For example, the national audit office of the republic of Afghanistan has set up a compilation of deadlines for removing the deadlines for the implementation of the code of conduct and collaboration on 16/3/85, which, in accordance with this document, provides for the proper performance of tasks and the establishment of appropriate operational programs for the identification of issues and the identification of functional priorities and information exchange and development. Information and inspection teams and joint accounts in the mandate and specific issues, and the compilation of the two-yearly report, will collaborate and collaborate. If this is the duty of the legislator, you must review the actions of the relevant laws in order to prevent it from happening.

Given the features of economic crimes that are high in black, such white collar offenders need to set up special units to investigate these crimes. By reviewing the rules, we find that such a reference is not foreseen in the law, although law enforcement agencies have been campaigning for police to fight economic crime in police affairs, but officials have not seen the necessary training in the field of finance. Officials have been advocating support for economic crime like some other countries seeking to pursue the case. The central economic units of the economic crimes center have also set up a central center for this. Like France, which created the central fighting combat officer in 2004, the most important office that specializes in tracking cases of economic crimes throughout the country, there is a multidisciplinary team of specialized specialist teams, and the coordination of civilian police forces and civilian intelligence officers in the preliminary investigation file. (Chegheni, 2011: 38). Therefore, the legislature, in keeping with the needs of the community in support of economic crime, needs to fill existing vacancies and comply with the relevant laws.

\section{Conclusion}

Economic crimes cause a recession, a loss of opportunity, and the spoilage of the country's vast economic resources, and the reduction of economic productivity, and, on the other hand, increase unemployment, poverty, economic recession, underground economy, and so on. Legal protection is one of the types of support for economic crime victims, which we find by reviewing laws. We are constantly faced with challenges in achieving the goals of protecting these victims, including: the plurality of law enforcement agencies, in addition to has caused the following problems and impediments such as inflation of the penal code, while at the same time did not lead to a single criminal policy in relation to economic crimes that lack the authority of the law through the interference of other authorities other than the Islamic consultative assembly in the legislative process and the adoption of laws that are often in themselves illegal admission is approved. Lack of transparency is one of the most fundamental challenges facing the victims of economic crime. Although measures have been taken in the last legislative activities of the past, these actions, which should have been influenced by the atmosphere of the community and the undergraduate approaches, have not yielded a brilliant record, for example, the anti-money laundering law, one of the most criticized laws of the year the past has been mentioned, or in the Islamic penal code, not only economic crime has not been defined, but only in an ambiguous commentary under article 109 of the said law (time-lapse rule), mentions some examples of this crime, and some crimes such as crimes related to stock exchange and ... As an economic offense not the phenomenon as well as the criminalization of bribery yet. Failure to comply with penalties is another challenge because it reduces the incentive to enter the criminal justice process.

Also, the imposition of imprisonment, which imposes many costs on society, does not adequately address the needs of the victims of these crimes, but the provision of compensation mechanisms for victims of economic crimes is an act of support for them. The lack of proper penalties in the field of criminal proceedings is an obstacle to the detection and prosecution of economic crimes. Similarly, shortcomings in international cooperation are also a legal challenge in protecting victims of economic crime, leading to a conflict between national and international competencies and judicial assistance that can be used to provide for the prosecution and extradition of offenders and the need to repair and amend relevant laws. Therefore, the need to recognize and fully define and comprehend the economic crimes and the various methods of their implementation, in accordance with the law, require the 
necessary legal texts, and to review the legal void and the complete correction of the legislative system to the point of law. Hama the need for economic crime is essential. Weak and unproductive intelligence agencies are proposing a reform of the law, which would add to the victim's harm rather than support. As mentioned, in order to get out of the regulatory challenge, suggestions are worthy of mention, including:

1. Defining economic crime and explaining its implications and eliminating ambiguities and reforming existing laws and regulations based on the needs of the community day.

2. The manuscripts passed by the expediency council and outside of the legal and regulatory powers are intended to prevent the creation of subsequent innovations in order to maintain the authority of the constitution.

3. The exclusion of such crimes from institutions such as amnesty, alternative punishment, etc., which in any way signify the certainty and punishment of these crimes, and reduce the authority and seriousness in punishing the criminal offenders.

4. Establishing penalties appropriate to the effects of economic crimes, especially money laundering.

5. Increased international engagement in line with judicial assistance, such as prosecution and extradition.

6. Attracting public participation in the fight against economic crime, establishing an independent and independent institution with adequate human and material resources, and anticipating cultural and educational measures for education and cultural development in society for the prevention of economic crime.

\section{BIBLIOGRAPHIC REFERENCES}

Ardebili Mohammad Ali. (2005). Intentional criminal law. Eighth edition

Gholduziyan (2004). Iraj, with public criminal law, tehran, tenth edition

Habibzadeh, M. J. (2004). Pathology of the criminal justice system. Journal of social sciences and humanities. Shiraz university. 21(2)

Hashemi Shahroudi, S. M. (2007). The context of corruption and economic context in Iran and the coping with it. Legal journal of justice, 61

Khodayan Chegheni, Z. (2012). A comparative study of criminal justice institutions in france and Iran in countering economic crime. Journal of legal studies of the fourth period, 2.

Kosha, J. (2008). Major economics compensation papers. Shahid beheshti university.

Mahdavi Pour, A. (2000) Differential penal policy in economic penance. Publishing rate

Massoudi Magham, A. A. (1992). Economic crime and criminal missions, doctoral dissertation on criminal law and criminology. Shahid Motahari University

Mohammadi, T., \& Omidvar, S. (2015). Interaction Effects of Human Capital and Institutions on the Economic Growth and its Implications for Iranian Economy. QJER, 15(1) 185-208 http://ecor.modares.ac.ir/ article-18-6179-en.html

Moradi, A. A. (2011). Messenger geopolitics from another perspective. Decentralization of knowledge. Academic jihad academic database, $43(78)$

Nejafi Abrandi Abadi, A. H. (2005). Criminal offenses of economic crime. Shahid beheshti university.

Noorzad, M. (2010) Economic crimes in Iran's criminal law. Jungle publishing

Rahbar, F. (2008). Cry fazlullah money laundering and ways to deal with it. Tehran University Press.

Saki, M. R. (2010) Criminal economic law, Jungle publishing

Seraj, A. (1998). Combating economic crime, chart of deviation, economic crime seminar. Research and research center 